Article

\title{
How Shall We Judge Agri-Food Governance? Legitimacy Constructions in Food Democracy and Co-Regulation Discourses
}

\author{
Julia Behringer* and Peter H. Feindt \\ Thaer Institute of Agricultural and Horticultural Sciences, Humboldt University at Berlin, 10099 Berlin, Germany; \\ E-Mails: julia.behringer@hu-berlin.de (J.B.), peter.feindt@hu-berlin.de (P.H.F.) \\ * Corresponding author
}

Submitted: 15 March 2019 | Accepted: 9 July 2019 | Published: 28 October 2019

\begin{abstract}
The food democracy discourse has emerged as a normatively grounded critique of an increasingly transnational agri-food system and its dominant co-regulatory mode of governance, where private and public norms and standards interact with public policy and regulation in complex ways. Analyzing competing agri-food discourses through a legitimacy lens can contribute to understanding how authority is transferred from traditional, hierarchical and state-centered constellations to a range of novel agri-food governance arrangements. This article reconstructs and compares the legitimacy constructions articulated in the co-regulation and the food democracy discourses, generating three key findings: first, there are two distinct articulations of food democracy discourse, which we label liberal and strong food democracy; second, while conceptualizations of legitimacy in the liberal food democracy and the co-regulatory discourse share many commonalities, legitimacy in the co-regulatory discourse relies more heavily on output, while the liberal food democracy discourse is more sensitive to issues of input and throughput legitimacy; third, the strong food democracy discourse articulates a critical counter-model that emphasizes inclusive deliberation which in turn is expected to generate a shared orientation towards the common good and countervailing power.
\end{abstract}

\section{Keywords}

agri-food governance; co-regulation; discourse; food democracy; governance; legitimacy; participation

\section{Issue}

This article is part of the issue "New Perspectives on Food Democracy" edited by Basil Bornemann (University of Basel, Switzerland) and Sabine Weiland (Université Catholique de Lille, France).

(C) 2019 by the authors; licensee Cogitatio (Lisbon, Portugal). This article is licensed under a Creative Commons Attribution 4.0 International License (CC BY).

\section{Introduction}

In recent decades, the governance of the agri-food system has increasingly involved private actors, including food producers, third-party auditors and certifiers, civil society organizations (CSOs), and food retailers. In this shift from public authority to hybrid food governance, responsibilities and interests collide, layer and diverge (Verbruggen \& Havinga, 2017). This practice of 'co-regulation' is reflected in an extensive academic and practitioner discourse. Public-private co-regulation has affected the "fundamental ways that people eat, how much they pay for food and how it reaches the dining table, mostly without public knowledge" (Rudder, Fritschler, \& Choi, 2016, p. 21). The challenge posed by global value chains to public oversight is exemplified by a frozen pizza in a supermarket in Ireland which, when tested by public authorities after the horse meat scandal in 2013, was found to contain ingredients from 35 countries that had transited through 60 countries and 5 continents (National Audit Office, 2013). In addition to concerns about how food is produced, distributed and consumed, there are also wider societal issues intertwined with co-regulation, including concerns over workers' rights, migration, ecological sustainability, gender issues, rural livelihoods, trade and global food security (Fuchs, Kalfagianni, \& Havinga, 2009).

A body of research and activism has emerged to debate how co-regulation establishes decision-making authority, and if this authority can or should be democrati- 
cally legitimized. As Havinga (2018) argues, unlike public bodies who derive legitimacy from democratic mandate, private sector organizations, such as retailers or agribusinesses, must find legitimacy through other strategies, such as claiming to speak for consumers or to deliver public goods. In this way, legitimacy can be created or questioned through discourses which connect norms and values to practices (Meyer \& Rowan, 1977).

The need of private actors in particular to "strategically influence the construction of legitimacy" has been widely recognized (Dendler \& Dewick, 2016, p. 240). While it is difficult to judge the discursive effects of such strategies (Leipold, Feindt, Keller, \& Winkel, 2019), it is worthwhile to reconstruct and critically assess logics of legitimacy, particularly as they deploy democratic norms to build a social license to operate (Suchman, 1995). While earlier research has explored constructions of legitimacy of co-regulation in agri-food systems (Fuchs \& Kalfagianni, 2010; Hachez \& Wouters, 2011; Halabi \& Lin, 2017) and in transnational public-private governance more generally (Flohr, 2010; Uhlin, 2010), our approach links legitimacy analysis of co-regulation to analysis of a discourse which challenges this "corporate system that sells food grown, processed and controlled thousands of miles away" (Johnston, Biro, \& MacKendrick, 2009, p. 510): the food democracy discourse.

Since WWII, co-regulation has evolved in several stages in response to major agri-food system changes: liberalization and globalization (Levi-Faur, 2009), advances in science (Winickoff, Jasanoff, Busch, Grove-White, \& Wynne, 2005), increases in inequality (Smith, 2009), and awareness of food scandals (Ansell \& Vogel, 2006). Beyond food security and availability, new and often interrelated concerns (i.e., food safety, quality, and later, social, environmental, animal welfare and climate issues) have evolved over time to encompass local, regional, national and transnational institutions with overlapping tasks (Feindt \& Flynn, 2009). To ensure reliable operation of today's globalized commodity markets, transnational value chains and differentiated consumer demands, a proliferation of private standards and norms has emerged which interact with national regulation and international law (Purnhagen, 2015). This co-regulatory system sits on top of producer-oriented agricultural policies that provide income support and often also legal exceptions for producers in many countries (Daugbjerg \& Feindt, 2017). Although private standards are only subject to private contract law, they have become de facto mandatory for many food producers in order to access food retail markets (Fuchs et al., 2009).

Since the 1990s, an emerging food democracy discourse has problematized the lack of public participation and accountability in the agri-food system, with a particular focus on reclaiming power from corporations (Lang, 1992, 1999). In contrast to the co-regulation discoursewhich stipulates a cooperative, complimentary and unavoidable nature of public-private co-regulation-the food democracy discourse revolves around a normative model of agri-food governance in which private actors remain firmly subjected to control by the demos through state oversight, market competition and civic activism. Thus, the food democracy discourse delineates public versus private control as a key battleground (Hassanein, 2008). Focusing on local consequences of global corporatization, food democracy proponents challenge the legitimacy of private standards and public-private coregulation. They aim to rebuild legitimacy of agri-food governance by establishing transparent and responsive framework conditions for the sustainable and just production and distribution of food, and for maintaining value for consumers and producers (Anderson, 2008).

Whether and how food democracy constitutes a successful counter-discourse to co-regulation is debated. Critics assert that food democracy may reinforce neoliberal norms of private food control (Johnston et al., 2009; Moragues-Faus, 2016). Alternative food movements that invoke democracy norms may mediate the "legitimation crisis" of corporate governance following food scares, and open "new and lucrative forms of consumption by endowing agribusiness with an image of responsibility and caring" (Guthman, 1998, p. 148). While food democracy proponents take issue with corporate control, many similar tropes and motives (e.g., the inclusion of ethical and sustainability concerns), drive both co-regulation and food democracy. A discursive analysis of legitimacy constructions can help to identify potential overlaps and incommensurability, which is a key step in understanding the contested political arguments embedded in current debates over control of agri-food governance; these debates include whether democracy norms apply to private actors, or whether traditional democracy norms devised for the relationship between states and citizens can be transferred to private organizations and consumers (Steffek, 2003). In examining the potential of a counterdiscourse such as food democracy, the degree to which other actors, such as states and civil society, help legitimize private control is also scrutinized. Though scholars of co-regulation (Wolf, 2006) and of food democracy (Anderson, 2008) argue that the state's inability or unwillingness to safeguard food values required more control by private actors, others, such as Sønderskov and Daugbjerg (2010), have found evidence that private standards rely heavily on states for legitimacy. Therefore, this article aims to answer the following research questions: How do dominant discursive and counter-discursive legitimacy constructions interlink or conflict in ways that produce new norms for agri-food governance? Within these constructions, how is democratic authority transferred and distributed across the public, private and civil society sectors?

As the basis for this discussion, we first outline a conceptual typology of legitimacy and our methodology for an analytical literature review. We then present our analysis, which finds two distinct articulations of food democracy, which we label liberal food democracy and strong food democracy. While the liberal food democ- 
racy discourse resonates with legitimacy constructions in the co-regulation discourse, strong food democracy constitutes a pronounced counter-discourse.

\section{Conceptual Framework: Legitimacy, Discourse and Power}

Legitimacy is considered a crucial element in creating and maintaining the power to govern. Following Weber (1922), legitimacy is rooted in the belief that the exercise of political-administrative power is in accordance with deep-seated normative and cognitive ideas. Legitimacy depends on "the belief in rightness of the decision or process of decision-making" (Dahl, 2006, p. 46). Legitimacy beliefs make it more likely that people adopt desired behaviors and accept decisions that they dislike, thereby decreasing the need to provide material incentives or to threaten the use of force (for a power-based interpretation of democratic legitimacy, see Bornemann \& Weiland, 2019).

The cognitive and normative beliefs about legitimacy are shaped by discourse, and in turn guide the design and support the authority of new policies and regulations (Feindt \& Oels, 2005; Leipold et al., 2019). A discourse is understood here as "an ensemble of ideas, concepts and categories through which meaning is given to social and physical phenomena, and which is produced and reproduced through an identifiable set of practices" (Hajer \& Versteeg, 2005, p. 175). From a discourse-analytical perspective, policies and regulations are products of "discursive contests over the framing of politics, actors, and underlying societal norms" (Fuchs \& Kalfagianni, 2010, p. 67).

Democratic legitimacy is a complex concept. Inspired by Abraham Lincoln's famous description of legitimate rule as government "of the people, by the people and for the people" (Williams, 1980, p. 259), a distinction between input legitimacy (rule by the people), output legitimacy (effectiveness for the people) and throughput legitimacy (quality of the governing processes) has been widely established in theories of democracy (Feindt, 2001; Scharpf, 1999; Schmidt, 2012). Norms of democracy are manifested differently in the agri-food system, e.g., via representation of specified stakeholder groups and forms of participation. For the purpose of our analysis, we have operationalized articulations of input, output and throughput legitimacy as expressed in agri-food governance discourses (see Table 1).

Input legitimacy is based on the belief that all citizens or all those affected have a fair and equal chance to influence authoritative decisions. It is linked to forms of political participation so as to ensure that governing bodies are accountable to those governed (Scharpf, 1999). In agri-food governance, consumers and citizens are used at times interchangeably as proxies for wider public representation (Hamilton, 2005). Participation requires further qualifiers such as inclusiveness and equality (Fuchs et al., 2009). Output legitimacy is based on the perceived capacity of a political system to effectively solve collective problems (Scharpf, 1999). The importance of output legitimacy reflects a level of delegated responsibility to experts and representatives (Majone, 1998). However, stakeholders will often prioritize some problems over others, or interpret solutions very differently (Fuchs \& Kalfagianni, 2009), so that output legitimacy can be contested. Output legitimacy is not necessarily linked to democratic processes and has therefore been inter alia criticized as an "effectiveness-based surrogate" for democratic norms (Hachez \& Wouters, 2011, p. 685).

Tensions between citizen participation and problemsolving effectiveness are frequent (Dahl, 2006). The radical plurality and complexity of contemporary societies

Table 1. Legitimacy types and indicators in agri-food governance.

\begin{tabular}{|c|c|c|}
\hline Legitimacy Type & Norms from democracy theory & Indicators for agri-food governance \\
\hline Input legitimacy & $\begin{array}{l}\text { Participation by the people; demands } \\
\text { articulated through formal and informal } \\
\text { channels and political mobilization (e.g., } \\
\text { protest, demonstrations, activism); inclusion } \\
\text { of all relevant knowledge }\end{array}$ & $\begin{array}{l}\text { Inclusive and equal opportunity for all food } \\
\text { consumers and producers for regular and } \\
\text { protected participation in the articulation of } \\
\text { demands, rule-making and monitoring; } \\
\text { inclusive representation on regulatory } \\
\text { bodies; inclusion of relevant local, } \\
\text { practitioner and scientific knowledge }\end{array}$ \\
\hline
\end{tabular}

Output legitimacy Efficiency for the people; effective solutions to collective problems; policies that benefit the majority; protection of minority rights

Throughput Legitimacy Processes with the people; efficacy of participation, accountability, transparency, inclusiveness and openness to interest consultation; reliable procedures; sound reasoning and inclusive deliberation; procedural justice
Perception of the efficient provision of safe, sustainable, healthy, culturally adequate food and diverse food choices for all societal groups

Institutionalized fair and orderly processes of deliberation, rule-making, implementation and monitoring-transparency, opportunity for meaningful participation processes, inclusive deliberation, responsiveness 
makes unanimous assessment of a given output unlikely (normative ambivalence) and causal attribution of systemic effects-such as rising obesity, biodiversity loss or antibiotic resistance-difficult. Throughput legitimacy denotes the belief that decisions and outcomes are based on transparent and reliable institutionalized processes. A belief that prescribed procedures have been followed makes it more likely that even undesired outcomes are accepted, e.g., a lost election or court case (Luhmann, 1969). However, compliance in transnational governance is typically less motivated by a belief in procedural arrangements than by substantive reasons and material interests (Mayntz, 2010). Throughput legitimacy has been described as bridging input and output legitimacy through the quality of institutional processes that ensure responsiveness to public demands (Fuchs et al., 2009; Schmidt, 2012). This requires productive, transparent and deliberative processes so that demands are "adequately channeled in societal and administrative decision-making, thereby improving accountability" (Schmidt, 2012, p. 24). The concept can be extended to apply to public-private and even to private agrifood governance. For example, deliberative procedures in transnational private governance would require deliberation between representatives of all affected stakeholders, and responsiveness beyond immediate business interests.

In order to reconstruct legitimacy in each discourse, a review of the research literature on food democracy and public-private co-regulation was conducted. In the next section, we discuss the methodological process of data collection and analysis, followed by the conceptual synthesis of the legitimacy constructions in co-regulation and food democracy discourse.

\section{Methodology}

As our primary objective is to explore co-regulation and food democracy through the lens of legitimacy, we conducted an analytical review of scholarly knowledge and grey literature in each field. The data collections were performed separately: first, a systematic literature review of food democracy (for a complete overview, see Behringer, 2019); second, we conducted a more focused search of literature on co-regulation and private agri-food standards which yielded both theoretical and empirical commentaries. These sources included peer-reviewed journals, edited book chapters, as well as grey literature on co-regulation prepared for institutions (Food and Agriculture Organization [FAO], World Bank, European Commission) which comment on historical influences, trends and motivations.

Based on these bodies of literature, a deductive content analysis examined occurrences of the indicators of the three types of legitimacy. For each discourse, we narrowed down the material to three empirical examples that are treated in the literature as representing the diversity of practices linked to each discourse and which illustrate different legitimacy constructions. For co-regulation, these examples include: (a) GlobalG.A.P., which assembles $50 \%$ of global retail and agribusiness value-added, and certifies food suppliers in 124 countries worldwide (GlobalG.A.P., 2019), making this the world's largest implementor of private agri-food standards (Hachez \& Wouters, 2011); (b) the Marine Stewardship Council (MSC), a collaboration of Unilever and the World Wildlife Foundation (WWF), working since 1996 to end unstainable seafood provision; and (c) organic standards, which originated from organic farmer associations and were later translated into international and regional public standards (Schwindenhammer, 2017). From the food democracy literature, we discuss: (a) community food hubs, which are mainly initiatives by small-scale producers and middle class families in reaction to corporate agri-food systems (Andretta \& Guidi, 2017); (b) the non-genetically modified organism (GMO) label campaign in the US backed by Food Democracy Now (Stephan, 2015) with a reported 650,000 farmers and citizen activists; and (c) the People's Food Policy initiative in Canada, led by city and provincial food policy councils.

\section{Legitimacy in the Co-Regulation Discourse}

In this section we examine how each type of legitimacy (input, output and throughput) is constructed in the co-regulation discourse to legitimize private governance norms and practices.

Input legitimacy in the co-regulatory discourse is mostly linked to the inclusion of relevant knowledge. Standards typically refer to scientific norms. Hatanaka (2014, p. 138) lists scientific norms such as perceived "disinterestedness, replicability and validity" as the foundational elements in establishing and universalizing the legitimacy of private agri-food governance, reflected in the ability to provide food conformity and harmonization despite diverse origins. This also applies to public agrifood governance. Winickoff et al. (2005, p. 92) cite proponents of science-based food regulation, who argue that it "can be, and should be, understood not as usurping legitimate democratic choices for stricter regulations, but as enhancing the quality of rational democratic deliberation about risk and its control." The intended result of the input of scientific norms and knowledge is therefore a sense of trustworthiness which adheres to rationality norms, although it has been criticized that science-based methods of risk management embody Western norms (Hatanaka, 2014; Winickoff et al., 2005).

The focus on knowledge inclusion prioritizes experts, albeit not necessarily scientists, in standard-setting processes. A closer look reveals that private standards are typically not developed by scientists but by sector experts (Fuchs et al., 2009). In GlobalG.A.P., standards are developed in technical committees with experts from retail, producers and traders (GlobalG.A.P., 2019), reflecting their expertise, but also their practical needs. 
At the same time, GlobalG.A.P. standards often refer to European public standards, potentially lending input legitimacy from the parliamentary process. However, GlobalG.A.P. extends these standards along the transnational value chains to territories where citizens had no input into the creation of the underlying public standards. Organic standards have been historically based on the principles developed by practitioners organized in organic farming associations and internationally harmonized through their umbrella organization International Federation of Organic Agriculture Movements, which later informed Codex Alimentarius standards and differentiated regional standards (Schwindenhammer, 2017). To the degree that the organic principles are not strictly based on scientific evidence, they present a different type of input legitimacy that is based on trust in the organic community's origins and values.

A second construction of input legitimacy is the adoption of democratic norms of inclusiveness through practices such as multi-stakeholder participation and representation of public interest. In GlobalG.A.P.'s membership model, for example, retailers and producers each elect $50 \%$ of representatives to the board, and additional associate members from food services and agricultural input firms consult in decision-making (Fuchs et al., 2009). Wider stakeholder participation was also introduced through focus groups, online public consultations, and country partners (GlobalG.A.P., 2019), including outreach to smallholder farmers in developing contexts who might be excluded from global value chains (Fulponi, 2006). Given this effort, FAO has deemed GlobalG.A.P. relatively open to stakeholder input (Henson \& Humphrey, 2009). Similarly, MSC garners input legitimacy through CSO involvement and government support. The MSC depends on participation of a highly trusted environmental NGO, WWF, and participation of affected stakeholders (Osterveer, 2015). MSC standards receive additional input legitimacy ex-post when they are absorbed into national regulations (Steets, 2011). Together, CSO involvement and government oversight, as Guthman (1998, p. 137) observes in the case of organic food standards, serve to "bolster and legitimize" agribusiness involvement as well as "palliate oppositional movements." Stakeholder participation, though emulating democratic input legitimacy, often remains unequal, privileging powerful retailers and large suppliers, with peripheral roles for consumers or farmers in the Global South (Tallontire, Opondo, \& Nelson, 2013). Even with CSO involvement, resource asymmetries prevent equal input from smaller actors and less well-resourced organizations (Steets, 2011).

Output legitimacy is constructed in co-regulatory discourse by emphasizing problem-solving capacity and efficiency to safeguard public goods and ethical concerns, interpreted as safe, abundant, ethical and 'natural' food choices for consumers. GlobalG.A.P., for example, was created in order to restore consumer confidence following state failures of food safety and loss of public trust (Havinga, 2018). Efficient harmonization also reduces costs and allows for process-based market differentiation. Similarly, the global harmonization of organic standards reassures consumers that products from around the globe adhere to the same principles (Schwindenhammer, 2017). The MSC scheme promises to safeguard the public good by prohibiting destructive fishing techniques and management of by-catch to meet WWF criteria, but also allows food retailers and services such as Wal-Mart and McDonald's to distinguish product lines for eco-minded consumers (Changing Markets Foundation, 2018). In essence, the output-based legitimacy of co-regulation has two underlying assumptions: that private standards need to complement public regulation to deliver on new consumer demands, and that these solutions are only sustainable when aligned with business interests. Output legitimacy is here constructed as inextricably linked to market creation because the private standards that complement public regulation enable new markets for emerging, differentiated consumer demands. Thus, the delivery of desired public goods and ethical outcomes synergize with the creation of opportunities for businesses and value chains that address these concerns.

The new consumer preferences, such as those for 'natural' food, in turn provide novel opportunities to increase output legitimacy through co-regulation. The discourse of organic standards, for example, allows value chain actors to construct their products as derived from natural sources. Some consumers perceive coregulatory standards as the most efficient, convenient means to "make nature safe and available" (Guthman, 2007, p. 150).

Output legitimacy of co-regulation is also constructed as fostering efficiency and innovation. Starting with the British Food Safety Law in 1990, responsibility for the methods to ensure safe food shifted towards the private sector. The European Commission (2017) advocates a "clear allocation of responsibility to foodhandling businesses and farmers to comply with EU rules associated with an obligation of self-control." Private standards and arms-length controls are heralded as creating the conditions for a "race to the top" (Levi-Faur, 2009 , p. 182), a catalyst for progress and modernization to improve supply chain capacity (World Bank, 2005), and as "more flexible and agile in responding to a wide range of continually evolving consumer preferences" (Smith, 2009, p. 5). Overall, we find that the construction of output legitimacy in the co-regulation discourse is derived from specific capabilities associated with the public, private and civil society sectors. Supposedly, only the interplay of societal demand, public-private co-regulation and business innovation delivers the desired outcome: safe, healthy, ethical and sustainable food on differentiated markets. The co-regulation discourse backgrounds that this system is mostly geared towards marketable features and the desires of a minority, namely wealthy consumers in the Global North (Fuchs et al., 2009). 
Throughput legitimacy in co-regulation discourse relates heavily to transparency and reliability processes via adherence with publicized procedures for standard setting, implementation and enforcement (Casey, 2017), traceability schemes and, to a lesser degree, the perception of deliberation among all relevant stakeholders. MSC boasts a high level of transparency via access to minutes of conferences, roundtables and videos (Fuchs et al., 2009). Objections panels provide stakeholders with means of formal complaint (Steets, 2011), while a Board of Trustees provides independent oversight (Fuchs et al., 2009). Reliable procedures "underline the professionalism and independence of the verification process" (Steets, 2011, p. 97). However, the construction of throughput legitimacy runs into limitations because the methodologies used and the results of the certification processes, for example audits of GlobalG.A.P.-certified food producers, are often confidential. Throughput legitimacy is achieved only insofar as internal private auditors provide credible public information, while private auditors may lack motivations for independence (Fagotto, 2017). Deliberation as a pillar of throughput legitimacy construction is emphasized in the MSC model, which strongly rests on its multi-stakeholder identity. At least in principle this allows for deliberation among possibly conflicting interests (Fuchs et al., 2009). The construction of throughput legitimacy in the co-regulation discourse again involves all sectors since private standards may also borrow throughput legitimacy via a level of government oversight or "orchestration" (van der Voort, 2015, p. 17). However, government oversight is inherently limited for any national jurisdiction in the face of transnational value chains.

Overall, our analysis shows a well-elaborated and complex construction of legitimacy in the co-regulation discourse: 1) the input legitimacy construct emphasizes expertise of scientists and practitioners, complemented by, albeit limited, participation opportunities for affected groups and stakeholders; 2 ) the output legitimacy construct connects effective and efficient provision of safe, healthy, sustainable and ethical food with the creation of differentiated markets through the interplay of public and private regulation; and 3) throughput legitimacy is constructed around notions of reliable, independent auditing, traceability, and varying degrees of transparency and deliberation in rulemaking.

\section{Legitimacy in Food Democracy Discourse}

We now turn to the construction of legitimacy in the food democracy discourse. Here, regarding input legitimacy, we find a strong emphasis on grassroots, communitybased participation to re-establish value-based agri-food systems. As Rossi (2017, p. 17) notes, values, knowledge and preferences "lead to the realm of food democracy." Undesired outcomes are explained by lack of valuebased democratic participation. For Food Democracy Now (Stephan, 2015), GMOs represent this distinct lack of values and public input. In the American context, the absence of mandatory GMO labelling is critiqued as denial of opportunities for value expression (Hamilton, 2005). While labelling is generally an element of throughput legitimacy by creating transparency, the absence of labels is seen as compromising input legitimacy by reducing choice options for consumers. With non-GMO activism, as Shiva (2003) argues, grassroots efforts can effectively combat the "denied freedom of information and freedom of choice because of corporate control and dependency." This is echoed by Anderson (2008) who points to the supermarket as a place where shoppers supposedly have unlimited choices, and yet the freedom to make critical decisions, such as avoiding GMO products, was unavailable. Here, input legitimacy in the food democracy discourse is constructed as political consumerism, where everyday food choices express individual ethical values (Andretta \& Guidi, 2017), and "each trip to buy food is really a visit to the polling place" (Hamilton, 2005, p. 22).

However, other voices in the food democracy discourse critique this form of political consumerism as a limited expression of self-interests (Hassanein, 2003) which may encourage corporate capture of values for the purpose of expanding new markets (Johnston et al., 2009). In contrast, the food policy council movement emphasizes collective participation in civic life alongside elected representatives in order to counteract a decoupling of states from society (Moragues-Faus, 2016). This is illustrated by the food policy councils where citizen consultation is protected by public act or joint resolutions (Fox, 2010). One of the Toronto food policy council's tasks has been "to propose policy at all levels of government, and to find ways of integrating community experiences" (Welsh \& MacRae, 1998, p. 249). Here, input legitimacy is linked to the knowledge and values of citizens and to direct interactions with municipal representatives.

Output legitimacy is constructed in the food democracy discourse by challenging the dominant paradigm of food provision through standardization and economies of scale (Lang, 1999). Pointing to trade-offs between efficiency and control, part of the food democracy discourse emphasizes efficacy of output, described by Hassanein (2008) as the combination of the capacity to act and make an impact. Efficacy is seen as important to maximize protection of the public good, though this is interpreted in different ways. As both Hassanein (2008) and Rose (2017) observe in community food initiatives, the capacity to act and impact is also felt in the hands-on production of food for alternative markets, particularly those which benefit lower-income consumers.

However, alternative constructions of output legitimacy emerge in the discourse that focus more on collective political efficacy than individual choice. From this perspective, individual efficacy may produce a sense of freedom and self-empowerment, but could subdue attempts at higher-level political change (Rossi, 2017). 
Output legitimacy then requires reduced individualism and, in its place, work towards the preservation of common pool resources and the adoption of good public policy. Here, the state, pressured into action by active food citizens, becomes the facilitator of a "new collectivism" (Lang, 1999, p. 221). An example for such a discourse that advocates a "people-centered, counterhegemonic policy-making process" (Levkoe \& Sheedy, 2017, p. 2) is the Canadian People's Food Policy. The output legitimacy of food councils in Canada is constructed through strengthening of common resources and a common sense of civic impact (Welsh \& MacRae, 1998). This reflects a two-dimensional construction of output legitimacy in the food democracy discourse, with consumer efficacy protecting freedom and choice, but also wider citizen-based structural efficacy. According to GómezBenito and Lozano (2014, p. 145):

If there were interest [sic] in highlighting consumers' obligations, the focus would be located beyond the market and would be oriented not only toward individual issues, but also toward structural factors and issues that affect the entire group of citizens.

Throughput legitimacy in the food democracy discourse requires high standards of transparency. This can be obtained through accountability to civil society through consumer information, or by directly empowering open citizen deliberation. In the first perspective, the state has a limited role to facilitate consumer education and to support alternative food movements, for example through financing community food hubs. Emphasis is put on private sector accountability to new consumer demands for transparency, and governance responsibility to address market failures through information asymmetry-e.g., by establishing non-GMO labels that enable consumers to avoid genetically modified products. Labels are also used by community food hubs as a way to self-certify, providing assurance that products are seasonal, nonindustrial, and fair, with the result that consumers could buy the product without question (Chiffoleau, MilletAmrani, \& Canard, 2016).

Although labels promote throughput legitimacy via transparency, parts of the food democracy discourse warn that a focus on labels may limit wider deliberation. For the decision-making process to be trusted, there must be the "opportunity to debate, to learn about the local food system and from each other, and to choose collectively what could be focused on and prioritized" (Chiffoleau et al., 2016, p. 10). Hassanein (2008) likewise notes that community coalitions require different interests to be negotiated. There is more promotion of transparent processes which guarantee food citizens a place in policy debates (Gómez-Benito \& Lozano, 2014). These debates, through food policy councils for example, can provide "some credibility in places where none would normally be possible" (Welsh \& MacRae, 1998, p. 251). In this vein, a democratic society "must be able to guaran- tee the meaningful and active involvement of all individuals, groups and institutions in decision-making" (People's Food Policy Project, 2011). This second food democracy perspective promotes inclusive deliberative processes to ensure accountability, and an inclusive and transparent political public sphere that is distinct from markets and not dominated by strategic interests.

Overall, our analysis of the food democracy discourse reveals two distinct articulations of each of the three dimensions of legitimacy:

1) While input legitimacy is strongly linked to valuebased knowledge and the application of democracy norms, the emphasis is either on the individual choices of concerned consumers or on citizens participating in collective action;

2) While output legitimacy is consistently based on efficacy and protection of the public good, efficacy is linked either to consumer freedom or to community resources;

3) Throughput legitimacy is mainly constructed either as transparency based on consumer information or as the opening up of wider, deliberative policy processes.

The two strands of the food democracy discourse characterized above resonate with established characterizations of 'liberal' and 'strong democracy' (Barber, 1984). We therefore propose to distinguish two distinct articulations of the food democracy discourse: the first, referred to here as liberal food democracy, emphasizes input legitimacy from consumer participation in order to pressure market actors to deliver products and services that correspond to consumers' ethical values. This vision conceives of output legitimacy as market responsiveness and maximized consumer choice, and throughput legitimacy as transparency, traceability and accountability. This form of participation has been criticized over a tendency to water down inclusion and reciprocity and to lose legitimacy due to overreliance on purchasing power (Renting, Schermer, \& Rossi, 2012). This aligns with Barber's (1984, p. 4) criticism of a lack of public accountability in liberal democracy, from which "no firm theory of citizenship, participation, public goods or civic virtue could be expected to arise."

The second articulation, strong food democracy, emphasizes citizen-based throughput legitimacy by way of processes which counter corporate power with civic power, public accountability, and state oversight (de Schutter, 2017; Hassanein, 2008; Moragues-Faus, 2016; for an example of strong food democracy that emphasizes participation and conflict as constitutive for food democracy, see Friedrich, Hackfort, Boyer, \& Gottschlich, 2019). In this articulation, the expected output is a common "ethics of interdependence, sustainability, health and justice over those of profit and individualism" (People's Food Policy Project, 2011). This reflects a call for strong interaction and collaboration, which resonates 
with Barber's (1984, p. 207) strong democracy concept where participation and "talk" creates a reciprocal environment, or a "listening citizenry." Its proponents argue that this strong interaction among citizens generates values of mutuality and reciprocity, interweaving inclusive input, participatory throughput and common goodoriented output legitimacy to represent an alternative form of agri-food governance.

\section{Discussion}

Our analysis reveals a complex interplay between competing concepts of input, throughput and output legitimacy in the co-regulation discourse and the two distinct articulations-liberal and strong-of the food democracy discourse (see Table 2 for an overview). From a reflexive governance perspective (Feindt \& Weiland, 2018), all three discourses constitute specific representations of the objects and subjects of agri-food governance, which creates potential barriers to mutual understanding and inclusive compromise. However, there is an observable overlap between the co-regulation and the liberal food democracy discourses; although the first is based on issues of coordination, problem-solving and harmonization and the second on value realization, responsiveness and accountability, both discourses overlap in putting consumer choice at the center of their conception of input legitimacy. Regarding output legitimacy, both discourses emphasize the conditions under which market mechanisms work to solve collective coordination and information problems. The result is a shared focus on procedures that create transparency along complex value chains through a system of standards, monitoring and labelling that evolves in response to changing consumer demands. Public goods can then be realized because consumers want them and 'vote with the dollar.'
Differences, however, remain. In the liberal food democracy discourse, as in classical theories of liberal democracy, fair and open competition is the main mechanism that generates a movement towards the public good and creates benefits for a majority. The role of the state is to guarantee public health and safety and to ensure a level playing field with regard to all other aspects, including that private standards are not misleading or used to stifle competition. From a liberal food democracy perspective, co-regulation in transnational value chains must therefore be linked to oversight through democratically controlled agencies with effective accountability to citizens and their elected representatives. In contrast, the coregulation discourse accepts dominantly private accountability arrangements as long as coordination problems are solved efficiently and the system is perceived as fair and reliable by market partners and consumers.

In contrast, the strong food democracy discourse emphasizes throughput legitimacy through open, inclusive and deliberative processes aimed at generating consensus and solidarity, and at producing common values and resources. It resonates with an expectation that is central to theories of Habermasian deliberative democracy: that common deliberation will transform participants' preferences and that the deliberating public will educate itself. Citizen-based networks and food councils express the idea that the agri-food system should mainly be governed by the shared deliberation of citizens, including in national and transnational fora, not by the fragmented transactions of consumers.

\section{Conclusion}

The food democracy discourse has emerged as a normatively grounded critique of an increasingly transnational agri-food system, where private norms and standards in-

Table 2. Comparison of legitimacy in co-regulation and food democracy discourses.

\begin{tabular}{|c|c|c|c|}
\hline Legitimacy type & $\begin{array}{l}\text { Co-regulatory food } \\
\text { discourse }\end{array}$ & $\begin{array}{l}\text { Liberal food democracy } \\
\text { discourse }\end{array}$ & $\begin{array}{l}\text { Strong food democracy } \\
\text { discourse }\end{array}$ \\
\hline Input legitimacy & $\begin{array}{l}\text { Voting with the dollar; } \\
\text { expertise }\end{array}$ & $\begin{array}{l}\text { Participation through } \\
\text { consumer choice, based on } \\
\text { purchasing power, and } \\
\text { representative democracy }\end{array}$ & $\begin{array}{l}\text { Participation of consumers } \\
\text { and producers as } \\
\text { deliberative citizens }\end{array}$ \\
\hline Output legitimacy & $\begin{array}{l}\text { Efficiency in satisfying } \\
\text { differentiated consumer } \\
\text { demand through public and } \\
\text { private standards that solve } \\
\text { information and } \\
\text { coordination problems }\end{array}$ & $\begin{array}{l}\text { Enhanced consumer choice } \\
\text { responding to societal } \\
\text { demand and values }\end{array}$ & $\begin{array}{l}\text { Efficacy within inclusive } \\
\text { agri-food systems; provision } \\
\text { of public goods; common } \\
\text { values }\end{array}$ \\
\hline Throughput legitimacy & $\begin{array}{l}\text { Compliance with public } \\
\text { regulations; transparency of } \\
\text { public and private } \\
\text { regulations; traceability, } \\
\text { auditing and quality } \\
\text { assurance }\end{array}$ & $\begin{array}{l}\text { Accountability through } \\
\text { delegated powers of public } \\
\text { agencies; state intervention } \\
\text { to address information } \\
\text { asymmetries }\end{array}$ & $\begin{array}{l}\text { Bottom-up, state-protected } \\
\text { networks of inclusive } \\
\text { deliberation based on food } \\
\text { citizenship }\end{array}$ \\
\hline
\end{tabular}


teract with public policy and regulation in complex ways that elude traditional models of democratic accountability. Our analysis aimed to reconstruct the underlying legitimacy constructions supporting co-regulation as well as food democracy conceptions. It generated three important insights: first, it is important to distinguish between two different articulations of the food democracy discourse, which we labelled liberal and strong food democracy; second, conceptualizations of legitimacy in the liberal food democracy and the co-regulatory discourse share an emphasis on market mechanisms and private sector initiatives. However, legitimacy in the co-regulatory discourse relies more heavily on output (delivering ample safe, reliable, sustainable and ethical food choices to improve consumer confidence in global food chains), while the liberal food democracy discourse is more sensitive to issues of input and throughput legitimacy such as fair opportunity for value expression and market power; and third, the strong food democracy discourse articulates a critical counter-model that emphasizes inclusive deliberation, which in turn is expected to generate reciprocal norms, a shared orientation towards the common good and countervailing power.

Our analysis contributes to linking two proliferating bodies of literature that address either co-regulation in agri-food governance (e.g., Verbruggen \& Havinga, 2017) or food democracy (Behringer, 2019). The focus on legitimacy constructions helps to better understand the contested political arguments embedded in current debates about governance of the agri-food system. Legitimacy constructions provide authority to models of social order embodied in a governance arrangement. Analytical reconstruction renders visible their historical contingency as the outcome of political struggles over power and control. Finding counter-discourses that challenge a dominant governance model and its discursive justification helps to clarify these struggles and the alternative models of authority and control at stake. Via discourses which emphasize the roles of actors other than state and civil society, democracy norms can be transferred to legitimize private authority over food. The presence of a counter-discourse, such as strong food democracy, makes such a legitimacy transfer more difficult andthrough its coordinative and mobilizing functions-has the potential to create new tensions and challenges for private power.

This contribution could only outline the competing constructions of legitimacy in agri-food governance. On this basis, we suggest three directions for future research. The first direction links up with political theory and history of political ideas and aims for a more in-depth inquiry into the legitimacy constructions, their historical roots and ideational resonance. The second direction links discourse analysis to a micro-analysis of regulatory practices and aims to assess how the different discourses affect the practice of co-regulation. The third direction takes a comparative approach and aims to understand how different regulatory practices and legitimacy claims interact in different countries and different value chains, and how they evolve over time. The combination of conceptual-argumentative, regulatory and comparative analysis will allow us to better understand whether and how the governance of agri-food systems lives up to democratic ideals and ambitions.

\section{Acknowledgments}

Julia Behringer's research is supported by the German Academic Exchange Service (DAAD).

\section{Conflict of Interests}

The authors declare no conflict of interests.

\section{References}

Anderson, M. D. (2008). Rights-based food systems and the goals of food systems reform. Agriculture and $\mathrm{Hu}$ man Values, 25(4), 593-608.

Andretta, M., \& Guidi, R. (2017). Political consumerism and producerism in times of crisis. Partecipazione $e$ Conflitto, 10(1), 264-274.

Ansell, C., \& Vogel, D. (2006). What's the beef? The contested governance of European food safety. Cambridge, MA: MIT Press.

Barber, B. (1984). Strong democracy: Participatory politics for a new age. Berkeley, CA: University of California Press.

Behringer, J. (2019). Food democracy or democracies? Recognizing liberal versus strong food democracy through a systematic literature review. Manuscript in preparation.

Bornemann, B., \& Weiland, S. (2019). Empowering people: Democratising the food system? Exploring the democratic potential of food-related empowerment forms. Politics and Governance, 7(4), 105-118.

Casey, D. (2017). Structuring private food safety governance: GLOBALG.A.P. and the legitimizing role of the state and rule intermediaries. In P. Verbruggen \& T. Havinga (Eds.), Hybridization of food governance: Types, trends and results (pp. 31-53). Cheltenham: Edward Elgar.

Changing Markets Foundation. (2018). The false promise of certification. Utrecht: Changing Markets Foundation. Retrieved from https://changingmarkets.org/ wp-content/uploads/2018/05/False-promise_fullreport-ENG.pdf

Chiffoleau, Y., Millet-Amrani, S., \& Canard, A. (2016). From short food supply chains to sustainable agriculture in urban food systems: Food democracy as a vector of transition. Agriculture, 6(4), 57. https:// doi.org/10.3390/agriculture6040057

Dahl, R. (2006). A preface to democratic theory. Chicago, IL: University of Chicago Press.

Daugbjerg, C., \& Feindt, P. H. (2017). Post-exceptionalism in public policy: Transforming food and agricultural 
policy. Journal of European Public Policy, 24(11), 1565-1584.

Dendler, L., \& Dewick, P. (2016). Institutionalising the organic labelling scheme in China: A legitimacy perspective. Journal of Cleaner Production, 134, 239-250.

de Schutter, O. (2017). The political economy of food systems reform. European Review of Agricultural Economics, 44(4), 705-731.

European Commission. (2017). Ensuring food is safe. The veterinary and phytosanitary system of the European Union explained. Luxembourg: Publications Office of the European Union.

Fagotto, E. (2017). Resolving gaps in third-party certification for food safety hybridization. In P. Verbruggen \& T. Havinga (Eds.), Hybridization of food governance: Types, trends and results (pp. 31-53). Cheltenham: Edward Elgar.

Feindt, P. H. (2001). Regieren durch Diskussion? Diskurs-und Verhandlungsverfarhen im Kontext von Demokratietheorie und Steuerungsdiskussion [Governance through discussion? Discourse and Negotiation in the context of democracy theory and steering discussion]. Frankfurt: Peter Lang.

Feindt, P. H., \& Flynn, A. (2009). Policy stretching and institutional layering: British food policy between security, safety, quality, health and climate change. British Politics, 4(3), 386-414.

Feindt, P. H., \& Oels, A. (2005). Does discourse matter? Discourse analysis in environmental policy making. Journal of Environmental Policy \& Planning, 7(3), 161-173.

Feindt, P. H., \& Weiland, S. (2018). Reflexive governance: Exploring the concept and assessing its critical potential for substantial development. Introduction to the special issue. Journal of Environmental Policy \& Planning, 20(6), 661-674.

Flohr, A. (2010). The role of business in global governance. Basingstoke: Palgrave Macmillan.

Fox, C. (2010). Food policy councils: Innovations in democratic governance for a sustainable and equitable food system. Berkeley: Goldman School of Public Policy, University of California. Retrieved from https://goodfoodlosangeles.files.wordpress.com/ 2011/01/fpc_final_dist-5-indd.pdf

Friedrich, B., Hackfort, S., Boyer, M., \& Gottschlich, D. (2019). Conflicts over GMOs and their contribution to food democracy. Politics and Governance, 7(4), 165-177.

Fuchs, D., \& Kalfagianni, A. (2009). Discursive power as a source of legitimation in food retail governance. The International Review of Retail, Distribution and Consumer Research, 19(5), 553-570.

Fuchs, D., \& Kalfagianni, A. (2010). The democratic legitimacy of private authority in the food chain. In T. Porter K. Ronit (Eds.), The challenges of global business authority: Democratic renewal, stalemate or decay? (pp. 65-88). Albany, NY: SUNY Press.

Fuchs, D., Kalfagianni, A., \& Havinga, T. (2009). Actors in private food governance: The legitimacy of retail standards and multistakeholder initiatives with civil society participation. Agriculture and Human Values, 28(3), 353-367.

Fulponi, L. (2006). Private voluntary standards in the food system: The perspective of major food retailers in OECD countries. Food Policy, 31(1), 1-13.

GlobalG.A.P. (2019). GlobalG.A.P. committees. GlobalG.A.P. Retrieved from https://www.GlobalG.A.P. org/uk_en/who-we-are/governance/committees

Gómez-Benito, C., \& Lozano, C. (2014). Constructing food citizenship: Theoretical premises and social practices. Italian Sociological Review, 4(2), 135-156.

Guthman, J. (1998). Regulating meaning, appropriating nature: The codification of California organic agriculture. Antipode, 30(2), 135-154.

Guthman, J. (2007). The Polanyian way? Voluntary food labels as neoliberal governance. Antipode, 39(3), 456-478.

Hachez, N., \& Wouters, J. (2011). A glimpse at the democratic legitimacy of private standards-Democratic legitimacy as public accountability: The case of GLOBALG.A.P. Journal of International Economic Law, 17(3), 677-710.

Hajer, M., \& Versteeg, W. (2005). A decade of discourse analysis of environmental politics: Achievements, challenges, perspectives. Journal of Environmental Policy and Planning, 7(3), 175-184.

Halabi, S., \& Lin, C. F. (2017). Assessing the relative influence and efficacy of public and private food safety regulation regimes: Comparing codex and GlobalG.A.P. standards. Food \& Drug Law Journal, 72, 262.

Hamilton, N. (2005). Food democracy II: Revolution or restoration? Journal of Law \& Food Policy, 1(13), 13-42.

Hassanein, N. (2003). Practicing food democracy: A pragmatic politics of transformation. Journal of Rural Studies, 19(1), 77-86.

Hassanein, N. (2008). Locating food democracy: Theoretical and practical ingredients. Journal of Hunger \& Environmental Nutrition, 3(2/3), 286-308.

Hatanaka, M. (2014). Standardized food governance? Reflections on the potential and limitations of chemicalfree shrimp. Food Policy, 45, 138-145.

Havinga, T. (2018). Private food safety standards in the EU. In H. Bremmers \& K. Purnhagen (Eds.), Regulating and managing food safety in the EU (pp. 11-37). Cham: Springer.

Henson, S., \& Humphrey, J. (2009). The impacts of private food safety standards on the food chain and on public standard-setting processes (FAO/WHO Paper). Rome: FAO. Retrieved from http://www.fao.org/3/ai1132e.pdf

Johnston, J., Biro, A., \& MacKendrick, N. (2009). Lost in the supermarket: The corporate-organic foodscape and the struggle for food democracy. Antipode, 41(3), 509-532. 
Lang, T. (1992). Food policy and public health. Public Health, 106(2), 91-125.

Lang, T. (1999). Food policy for the 21st century: Can it be both radical and reasonable? In M. Koc, R. MacRae, L. J. A. Mougeot, \& J. Welsh (Eds.), For hunger-proof cities: Sustainable urban food systems. (pp. 216-225). Ontario: International Development Research Center.

Leipold, S., Feindt, P. H., Keller, R., \& Winkel, G. (2019). Discursive analysis of environmental policy: Tradition, trends, perspectives. Journal of Environmental Policy \& Planning, 20(5), 445-463.

Levi-Faur, D. (2009). Regulatory capitalism and the reassertion of the public interest. Policy and Society, 27(3), 181-191.

Levkoe, C., \& Sheedy, A. (2017). A people-centered approach to food policy making: Lessons from Canada's People's Food Policy project. Journal of Hunger \& Environmental Nutrition, 14(3), 318-338.

Luhmann, N. (1969). Legitimation durch Verfahren [Legitimation through procedure]. Neuwied: Luchterhand.

Majone, G. (1998). Europe's 'democratic deficit': The question of standards. European Law Journal, 4(1), 5-28.

Mayntz, R. (2010). Legitimacy and compliance in transnational governance (MPIfG Working Paper No. 10/5). Cologne: Max Planck Institute for the Study of Societies.

Meyer, J., \& Rowan, B. (1977). Institutionalized organizations: Formal structures as myth and ceremony. The American Journal of Sociology, 83(2), 340-363.

Moragues-Faus, A. (2016). Emancipatory or neoliberal food politics? Exploring the "politics of collectivity" of buying groups in the search for egalitarian food democracies. Antipode, 49(2), 455-476.

National Audit Office. (2013). Food safety and authenticity in the processed meat supply chain (Report No. HC 685). London: The Stationery Office.

Osterveer, P. (2015). Authority and legitimacy in governing global food chains. In T. Havinga, F. Van Waarden, \& D. Casey (Eds.), The changing landscape of food governance: Public and private encounters (pp. 117-133). Cheltenham: Edward Elgar Publishing.

People's Food Policy Project. (2011). Food democracy and governance, resetting the table: A people's food policy for Canada. Montreal: Food Secure Canada.

Purnhagen, K. (2015). Mapping private regulation: Classification, market access and market closure policy and law's response. Journal of World Trade, 49(2), 309-323.

Renting, H., \& Schermer, M., \& Rossi, A. (2012). Building food democracy: Exploring civic food networks and newly emerging forms of food citizenship. International Journal of Sociology of Agriculture and Food, 19(3), 289-307.

Rose, N. (2017). Community food hubs: An economic and social justice model for regional Australia? Rural Society, 26(3), 225-237.
Rossi, A. (2017). Beyond food provisioning: The transformative potential of grassroots innovation around food. Agriculture, 7(1), 6.

Rudder, C. E., Fritschler, A. L., \& Choi, Y. J. (2016). Public policymaking by private organizations: Challenges to democratic governance. Washington, DC: Brookings Institution Press.

Scharpf, F. (1999). Governing in Europe. Effective and democratic? Oxford: Oxford University Press.

Schmidt, V. (2012). Democracy and legitimacy in the European Union revisited: Input, output and 'throughput'. Political Studies, 61(1), 2-22.

Schwindenhammer, S. (2017). Global organic agriculture policy-making through standards as an organizational field: When institutional dynamics meet entrepreneurs. Journal of European Public Policy, 24(11), 1678-1697.

Shiva, V. (2003). Food democracy v. food dictatorship. $Z$ Magazine. Retrieved from https://zcomm.org/ zmagazine/food-democracy-v-food-dictatorship-byvandana2-shiva

Smith, G. (2009). Interaction of public and private standards in the food chain (OECD Food, Agriculture and Fisheries Papers, No. 15). Paris: OECD Publishing.

Sønderskov, K. M., \& Daugbjerg, C. (2010). The state and consumer confidence in eco-labeling: Organic labeling in Denmark, Sweden, The United Kingdom and The United States. Agriculture and Human Values, 28(4), 507-517.

Steets, J. (2011). Accountability in public policy partnerships. Basingstoke: Palgrave Macmillan.

Steffek, J. (2003). The legitimation of international governance: A discourse approach. European Journal of International Relations, 9(2), 249-275.

Stephan, H. (2015). Cultural politics and the transatlantic divide over GMOs. Houndsmills: Palgrave Macmillan.

Suchman, M. (1995). Managing legitimacy: Strategic and institutional approaches. Academic Management Review, 20(3), 571-610.

Tallontire, A., Opondo, M., \& Nelson, V. (2013). Contingent spaces for smallholder participation in GlobalG.A.P.: Insights from Kenyan horticulture value chains. The Geographical Journal, 180(4), 353-364.

Uhlin, A. (2010). Democratic legitimacy of transnational actors: Mapping out the conceptual terrain. In E. Erman \& A. Uhlin (Eds.), Legitimacy beyond the state? London: Palgrave Macmillan.

van der Voort, H. (2015). The meta-governance of coregulation: Safeguarding the quality of Dutch eggs. In T. Havinga, F. Van Waarden, \& D. Casey (Eds.), The changing landscape of food governance: Public and private encounters (pp. 238-257). Cheltenham: Edward Elgar.

Verbruggen, P., \& Havinga, T. (Eds.). (2017). Hybridization of food governance. Cheltenham: Edward Elgar.

Weber, M. (1922). Wirtschaft und Gesellschaft [Economy and society]. Tübingen: Mohr.

Welsh, J., \& MacRae, R. (1998). Food citizenship and com- 
munity food security: Lessons from Toronto, Canada. Canadian Journal of Development Studies, 19(4), 237-255.

Williams, T. H. (Ed.). (1980). Selected writings and speeches of Abraham Lincoln. New York, NY: Hendricks House.

Winickoff, D., Jasanoff, S., Busch, L., Grove-White, R., \& Wynne, B. (2005). Adjudicating the GM food wars: Science, risk, and democracy in world trade law. Yale Journal of International Law, 30, 81-123.
Wolf, K. D. (2006). Private actors and the legitimacy of governance beyond the state. Conceptional outlines and empirical explorations. In A. Benz \& I. Papadopoulos (Eds.), Governance and democracy. Comparing national, European and international experiences (pp. 200-277). London: Routledge.

World Bank. (2005). Food safety and agricultural health standards: Challenges and opportunities for developing country exports (Report No. 31207). Washington DC: The World Bank.

\section{About the Authors}

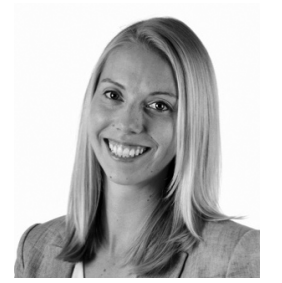

Julia Behringer, Humboldt University at Berlin, is a Doctoral Candidate in Food \& Agriculture Policy. Julia holds an MA in Environment and Development Studies from King's College London and previously worked at the Centre for Agriculture and Bioscience International in the UK and Switzerland. She is a recipient of the German Chancellor's Fellowship of the Alexander von Humboldt Foundation and a doctoral scholarship from the German Academic Exchange Service. Her primary research interests include citizen participation, democracy theory, climate, environmental and agricultural transitions and sustainable diets. She is Co-Founder of the Food \& Democracy Doctoral Research Cluster and Associate Member of FoodBerlin.

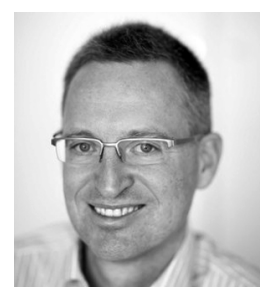

Peter H. Feindt, Humboldt University at Berlin, is Professor of Agricultural and Food Policy. He previously held positions at the University of Hamburg, Cardiff University and Wageningen University. His research interests include agricultural and food policy, environmental policy, sustainability transitions, resilience of farming systems, public participation and conflict management, policy discourse and narratives. Peter is Co-Editor of the Journal of Environmental Policy and Planning and chairs the Scientific Advisory Council for Biodiversity and Genetic Resources at the German Federal Ministry of Food and Agriculture. 